Pamukkale University Journal of Social Sciences Institute

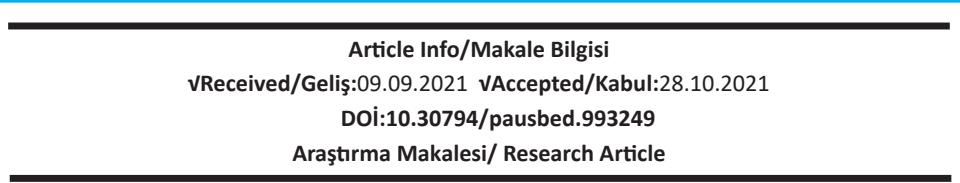

Dayan, C. ve Yüksel-Kaptanoğlu, i. (2022). "Online Focus Groups and in-Depth Interviews: What Can Our Experiences Articulate?", Pamukkale University Journal of Social Sciences Institute, Issue 49, Denizli, ss.59-67.

\title{
ONLINE FOCUS GROUPS AND IN-DEPTH INTERVIEWS: WHAT CAN OUR EXPERIENCES ARTICULATE?
}

\author{
Cansu DAYAN*, illknur YÜKSEL-KAPTANOĞLU**
}

\begin{abstract}
Online interviewing has increasingly begun to be preferred in qualitative research in recent years. Here, we aim to discuss our methodological experiences based on e-field of the PhD thesis designed with a qualitative approach on poverty measurement. For this, we narrate our strategies improved for in-depth interviews and synchronous focus group discussions conducted in a 5-month-process through Zoom, categorizing them as before, during and after interviews. Scrutinizing our strategies, we discuss situationally prominent key characteristics of the e-field. Within this scope, we find out that the quality of infrastructure, keeping the duration of the interview short and the number of the questions and participants less than the traditional interviewing are significant factors. Last, we find it crucial to indicate that some outcomes of the e-field can have ambivalent characteristics and obligate the researchers to make selections.
\end{abstract}

Keywords: Qualitative research, Online interviewing, Focus group, In-depth interview.

\section{ÇEVRIMIÇi ODAK GRUP GÖRÜŞMELERI VE DERINLEMESINE MÜLAKATLAR: DENEYIMLERIMIZ NE SÖYLÜYOR?}

öz

Çevrimiçi görüşmeler son zamanlarda giderek artan bir şekilde nitel araştırmalarda daha fazla tercih edilir hale geldi. Biz de bu çalışmada, yoksulluğun ölçülmesi konusunda nitel yaklaşımla yürüttüğümüz doktora tez çalışmasının çevrimiçi saha çalışmasına dayanan metodolojik deneyimlerimizi tartş̧mayı amaçlıyoruz. Bunun için, Zoom uygulaması aracılı̆̆ıyla 5 aylık bir süre içinde gerçekleştirdiğimiz senkron odak grup görüşmeleri ve yarı-yapılandırılmış derinlemesine görüşmeler için geliştirdiğimiz stratejileri görüşmeler öncesi, esnası ve sonrasında olmak üzere gruplandırarak aktarmayı hedefliyoruz. Belirlediğimiz stratejileri ayrıntlandırarak çevrimiçi saha çalışmamızda durumsal olarak öne çıkan başlıca özgünlükleri tartş̧ıoruz. Bu bağlamda, teknik altyapının kalitesi, yüz yüze görüşmelere kıyasla görüşme süresinin kısalığı ile soru ve katılımcı sayılarının düşüklüğünün önemli etkenler olduğunu saptadık. Son olarak, çevrimiçi saha çalışmasının bazı sonuçlarının ikircikli bir doğaya sahip olduğunu ve araştırmacıları seçim yapmak durumunda bırakabileceğini paylaşmayı da önemli bulduğumuzu belirtmek isteriz.

Anahtar kelimeler: Nitel araştırma, Çevrimiçi görüşme, Odak grup, Derinlemesine görüşme.

\footnotetext{
*PhD, Hacettepe University, Institute of Population Studies, Social Research Methodology Dept. and YÖK 100/2000 Fellow in Poverty Studies in Economics Dept., ANKARA.

e-mail: cansu.dayan03@gmail.com (https://orcid.org/0000-0003-2242-2979)

**Assoc Prof, Hacettepe University, Institute of Population Studies, Social Research Methodology Dept., ANKARA

e-mail: ilknury@hacettepe.edu.tr (https://orcid.org/0000-0001-5969-1238)
} 
Qualitative research has been one of the most debated issues of social sciences since the early 1990 s. Focusing on "exploring and understanding the meaning individuals or groups ascribe to a social or human problem" (Creswell and Creswell, 2018: 41), it has been attempted to be defined and framed for many times. Yet, as Mason puts it directly, "qualitative research - whatever it might be - certainly is not a unified set of techniques or philosophies, and indeed has grown out of a wide range of intellectual and disciplinary traditions" (Mason, 2002: 2). Ranged from modernist to postmodernist approaches (Garfinkel, 1967; Blumer, 1969; Schutz, 1976; Fairclough, 1992; Glesne and Peshkin, 1992; Stanley and Wise, 1993; Denzin and Lincoln, 1998; Wetherell, Taylor and Yates, 2001; Saldaña 2009; Savin-Baden and Major, 2010), this enriched ground that qualitative research has been ascended on brings together a grand spectrum of components that help constitute affluent characteristics of qualitative research. Within this sense, the nature of social reality, the properties of knowledge, the ways of generating data, the selection of research topics, the positionality of the researcher, the participants of the research, the style of presenting the data change in accordance with the approach we embrace. For Mason, these characteristics include the requirements of qualitative research to be systematically and rigorously conducted, accountable, strategically conducted yet flexible and contextual, actively reflexive, producing explanations and arguments rather than mere descriptions, generalizable in some way, not antithetical to quantitative research, and conducted as a moral practice (2002: 8). While for Creswell and Creswell (2018), natural setting, researcher as key instrument, multiple sources of data, inductive and deductive data analysis, participants' meanings, emergent design, reflexivity, and holistic account compose the main characteristics (257-8). Setting the relationship between the researcher and the participants non-hierarchically and interactively with the aim of generating situated knowledges (Haraway, 1991), qualitative research acknowledges the significance of the specificities of the subjectivities with regard to the situation, context, location, condition and alike. In other words, as Glesne and Peshkin (1992) specify, "in qualitative research, face-to-face interactions are the predominant distinctive feature". However, recently, the mode of qualitative researching has varied from traditional face-toface interactions to online, and immersive virtual world settings (Savin-Baden, Gourlay \& Tombs, 2010).

In accordance with the characteristics of qualitative research, in this study, we aim to share our qualitative e-field experiences by reference to semi-structured in-depth interviews and synchronous focus group discussions with a highlight on the importance of the specificities of a research rather than giving a general account of ads and cons of online interviewing in comparison to face-to-face interviewing as it is mainly addressed in literature. As a part of a PhD dissertation whose focus is on multi-dimensional poverty measurements, this fieldwork rises upon grounded theory and feminist standpoint. As constituents of qualitative research, grounded theory requires a flexible stance while feminist standpoint asserts a self-reflexive and active voice language, as which will welcome the reader in this study. Since this study is generated within the scope of my PhD dissertation, we, my supervisor and I, have designed the methodology of the research collaboratively and interactively while, as the researcher, I conducted the research fieldwork and data generation processes. Therefore, the subject pronouns of ' $w e^{\prime}$ ' and ' $\mathrm{l}$ ' will be used throughout the text to indicate the agents of the act. By sharing scrutinized strategies of the stages of the e-fieldwork with a methodological approach rather than focusing on the results of the $\mathrm{PhD}$ research, we think and hope that we can be of support to qualitative researchers planning to conduct online qualitative fieldworks.

\section{WHAT PREVIOUS RESEARCH SAYS ABOUT ONLINE INTERVIEWING?}

The use of internet in social research has been introduced and practiced since the beginning of the 1990s. In literature, sampling is mentioned as an advantage with the possibility to reach an extensive population and as a disadvantage for coverage and sampling errors related to the generalization in the quantitative research. However, reduced cost and time are among the main advantages of online quantitative and qualitative research. Many studies focus on the comparisons of the use of online methods to traditional ones in different disciplines (Mehda and Sivadas, 1995; Hewson, 1996; Bloor, Frankland, Thomas and Robson, 2001; Beddows, 2008; Tates et al., 2009; Lupton, 2021). Ethical problems in online research are also mentioned as one of the disadvantages noting that basic principles are not determined (Dogan, 2020). Among the advantages, recruitment issues, participant convenience, researcher benefits, quality of the data obtained, cost and time-savings, unconstrained place of participation have particularly been documented along with the critical evaluation that the internet "allows new recruitment opportunities for ill or disabled participants, housebound respondents, marginalized populations, and socially or geographically isolated people" (Tates et al., 2009). 
It is no wonder that the studies about the online quantitative and qualitative research have been more discussed in the pandemic period. The number of special issues of the journals and webinars organized by international and national research institutions are increasing globally (Adalı et al., 2021). In those webinars, the influence of COVID-19 on the ongoing surveys, changes in methods in quantitative, qualitative and mixed methods are widely discussed. The World Association for Public Opinion Research (WAPOR) and American Association for Public Opinion Research (AAPOR) are some of the examples for the institutions that organized specific webinars on qualitative research to discuss the challenges. In one of the webinars of WAPOR, it is indicated that transferring the qualitative research from traditional to online is evaluated as hard especially for focus groups (qtd in Adalı et al., 2021: 57).

In Turkey, on the other hand, a few studies (Kısakulakoğlu, 2014; Dogan, 2020) have discussed online researching up to now but it is increasing since many researchers have changed their techniques and continued to generate data using qualitative, quantitative or mixed methods approach. Among these studies, a few (Adalı et al, 2021; Sociology Association, 2021) focus on methodological challenges.

\section{WHAT WE DESIGNED?}

In my PhD dissertation, I study poverty measurement methodologies. To proceed with Mason, "all qualitative research should be constructed around an intellectual puzzle of some kind, and should attempt to produce some kind of explanation of that puzzle, or an argument" (2002:18). With this in mind, in order to understand poverty, broaden its definitions and enrich the measurements, we designed a qualitative research through focus group interviews and semi-structured in-depth interviews.

We started the preparations and conduct of my fieldwork in the beginning of 2021 which corresponds to a period when we were struggling with the Covid-19 pandemic. As Lobe et al. (2020) addresses, "[i]n a time of unprecedented change and disruption due to COVID-19, qualitative researchers face unique opportunities and challenges". Keeping these in mind, we planned the whole fieldwork as online rather than facing the risks of traditional face-to-face interviewing in regards to health concerns, lockdowns, low participation and similar. Of course, online interviewing did not seem less risky from the aspects of technical issues and quality of data; however, we preferred technical problems instead of health problems. In addition, we thought that, with the help of the strategies situationally determined before, during, and after interviews, we could technically manage to take the control of the e-field more efficiently than the traditional one. McCartan et al. (2012) suggest the use of texting with smartphones to be one of the practical and innovative techniques in online interviewing; however, we decided on the use of interactive video conferencing in accordance with the demands of our research inquiry, as Sullivan (2012) evaluates it to be appropriate for data generation in qualitative research. From various platforms, we selected Zoom application due to its characteristics including real-time audio, fullmotion video, video recording, user-friendliness, non-compulsion for participants to download the application and/or to have an account for attending any meeting (Lobe et al., 2020: 2-3).

The sample comprised participants from different backgrounds as academia, civil society, public sector, and art world, who are directly related to the research topic. For convenience, we addressed these backgrounds categorically but most of the participants had naturally intersecting backgrounds. The participants' selection was based on their interest on the research topic, and they were reached by key informants and the institutions related to the research topic as well as searching personal websites and the social media platforms such as Instagram. Within this scope, we tentatively planned the fieldwork to consist of 20 in-depth interviews and 6 focus group interviews as 2 heterogeneous and 4 homogenous, bearing the recurrence of the data in mind. Upon preparing the guidelines and informed consents for both in-depth interviews and synchronous focus group discussions ensuring the anonymity, confidentiality and security of the participants along with the voluntary basis of their participation, we applied to the Ethical Commission of the Hacettepe University.

\section{HOW WE CONDUCTED THE FIELDWORK?}

Aware of the fact that keeping the promises of our ethical conduct in an online platform would be harder and we might have challenges in persuading people to trust us and attend the interviews, we had thought of 
solutions and precautions prior to our application for ethical approval, even though we had to develop new and more effective ones during the fieldwork, as well. As Mason indicates "in qualitative research, decisions about design and strategy are ongoing and are grounded in the practice, process and context of the research itself. However, although qualitative researchers should not aim to produce entire advance blueprints, in my view, they very definitely should nevertheless produce a research design at the start of the process. The main proviso is that thinking about strategy and design should not stop there" (Mason, 2012: 24). We find it significant to indicate that the topic on which we are studying and the subjects of the topic are critical in the application of these solutions and precautions. Since our study is, in the broadest sense, on methods and measurement, our semi-structured interview guidelines did not contain sensitive questions that might be challenging to ask and brainstorm online. In addition, we used purposive (theoretical) sampling for our research whose subjects ipso facto are mostly people with high level of education, technological literacy and availability. Purposive sampling

means selecting groups or categories to study on the basis of their relevance to your research questions, your theoretical position and analytical framework, your analytical practice, and most importantly the argument or explanation that you are developing. Theoretical sampling is concerned with constructing a sample (sometimes called a study group) which is meaningful theoretically and empirically, because it builds in certain characteristics or criteria which help to develop and test your theory or your argument (Mason, 2002:14).

We were aware that we would miss those who did not have the necessary technological substructure whom we might have the chance of interviewing in traditional face-to-face methods; however, the pandemic has reduced this possibility of missing people to a lesser extent, if not to zero, by enhancing the rates of ownership of a computer/internet and internet use in comparison to a non-pandemic period. Keeping in mind that each research has its unique design in accordance with its aims, research questions and sources, we can say that we were lucky from the aspects of our topic and its subjects. In addition, we paid specific attention to the existence of disadvantaged identities from ethnicity, age, sex, class to sexual orientation, willingly and purposefully inviting NGOs and activists working in the related areas.

\section{Before the Online Fieldwork: Recruitment, Initial Contacts and Follow-up}

Recruitment of the participants both in in-depth interviews and focus group discussions is an important part of the planning of a fieldwork even in the face-to-face fieldwork. After deciding the characteristics of the participants and compositions of each focus groups, the initial contacts with the potential participants, invitations and follow-up procedures are significant to guarantee their participation (Morgan and Krueger, 1998). It is a well-known fact that, to find the interested participants on the research topic is not easy all the time. Since we have different target groups, we spend more time for recruitments. We prepared a list of potential participants according to the eligible criteria for our research topic and tried to find the desired participants.

Immediately after receiving ethical approval, I started the fieldwork in March, 2021. From the very beginning until the end, I preferred written communication, specifically e-mails as my communication medium so that the information regarding our identities, contact addresses, our research, the rights of the participants, places they can ask and prove or report the research/ers in any case can be clear, savable and reliable. Although communication through e-mails has the risk of slowing down the process and of no replies, I preferred it against any disturbance that phone calls and/or WhatsApp messages might cause, i.e. doubt and mistrust. If I did not have the e-mail information of the participants at first contact, I used mentioned alternatives to request for e-mail information. I did not use a common template in the e-mails, instead I preferred writing personal and situationally composed e-mails, which took more time and energy yet felt sincerer and more attached for both sides. Besides, I kept reminding the participants our responsibilities towards them and their rights in nearly all e-mails, at the risk of being boring.

When I got acceptances and decided on the date of the interviews, I opened the phase of reminding myself via day-by-day e-mails until the interview date arrived. First, I shared detailed information about the whole process and aspects of the interviews such as the duration, questionnaire guideline and question types for both in-depth interviews and focus group discussions, the general profile of the participants, technical information, 
what I expect from the participants and what I can provide, and especially the information that declared I was to continue my e-mails until the day of the interview.

Then, I shared a Google form which I had prepared for focus group discussions with the aim of properly getting personal information that might be lost in the shuffle, such as age, education, job, institution, field, the place of participation to the interview and alike. Google forms have played another significant role as I requested the permissions of the participants for voice and video records through them. In in-depth interviews I had asked this immediately before the interview started. However, in focus groups this would be risky regarding the organization of the discussion, ethical responsibilities and time issues. On the other hand, sharing the forms the day before the interviews enabled me to track the participants if they were still with us by means of participants filling-in their forms without directly asking to and bothering them, and brought me extra time to handle the situation if they were not. Towards the end, in the morning of the interview, I shared the link of the meeting so as to ensure the security of the interview and reminded them for the last time. In all of the collective e-mails sent before the interviews, I used bcc to protect the privacy of the participants. I took the responsibility of moderating the focus group discussions and conducted the interviews under the guidance of my thesis supervisor.

\section{During the Online Fieldwork: Conducting In-depth Interviews and Moderating Focus Groups}

When the interviews started I, once again, repeated the significant information that I had previously shared via e-mails. I requested the participants to keep their videos on and not to use some features of Zoom unless it was really necessary, such as raising hands, which might cause changes in the screen and confuse and/or disturb one's concentration. If any participant did not feel comfortable with video recording s/he kept the camera off. We also suggested nicknames option but nobody in our interviews needed to use that option. In contrast, the real names being ceaselessly shown on the screen helped the participants to follow and address each other with their names and warmed the atmosphere faster than face-to-face interviews in which the participants might not remember and/or confuse the names of other participants in the absence of nametags.

We did not define a rule for the voice to be muted or unmuted in the beginning, but in due course it turned out to be necessary for the quality of the interviews and of course transcription process. Keeping unmuted while one was speaking prevented background noises; what is more, the action of muting and unmuting signified that one had finished her/his speaking and/or another had something to say. Necessitating to follow each other and preventing interruptions, this silent communication enhanced the dynamics of the group, as well.

After the participant/s settled and felt ready, I started the recording, which took nearly the first five-ten minutes in each interview. For both in-depth interviews and focus groups, we did not prefer having an observer. We thought both video/voice recording and an observer would be too much from the aspects of the participants as voice and video recording would, in one hand, sufficiently enough cause the feelings of being gazed, and would on the other, function like an observer.

I, as the interviewer/moderator, played the role of a facilitator and was there to motivate the participants. During the focus group discussions, leaving the floor to the participants as a moderator and enduring the long silences turned out to be crucial to bring the participants back to the discussion. Sometimes I used pass-the-ball technique ${ }^{1}$ in introduction and meeting sessions to create connections between and among the participants and to establish a speaking order free from the interferences of the moderator, through which I observed that the participants owned the group as theirs and felt much belonged.

In focus group discussions, we had previously planned to have 6-8 participants as suggested optimum range. However, in practice, the arranged participant number had always changed due to last minute withdrawals/ attendances and I ended up with the range of 4-7. Realizing that with increasing number of participants, either the duration of the interview increases or the number of questions decreases, I found out the ideal number of the participants in an online focus group to be 6 , thenceforward I intentionally aimed at 6 participants for each group so that we could have the chance of deeply focusing on the topic for $2-2,5$ hours. The number of the

1 For our case, one of the participants starts introducing her/himself and passes a virtual ball to another participant s/he would like to meet, and this goes on until everybody gets to know each other. For further information, see https://powerfulpanels.com/virtual-paneldiscussion-technique/ 
questions raised were no more than five, which meant that each question was discussed for at least half an hour by all group members. Ending the interview at previously decided and declared time had always been important keeping in mind that everybody had already been suffering from Zoom fatigue and even 2 hours had been long enough for some participants especially for those who were working.

Leaving aside the group dynamics and interaction which is the first and foremost determining factor also in traditional interviewing, the quality of the technical infrastructure has by landslide determined the quality of the interviews in online interviewing. For us, the quality of the technical infrastructure is composed of the quality of the internet service, the quality of technological equipment from computer to camera and headphone, and the quality of the place to attend the interview from being alone to silence, brightness and airiness.

During the interviews, we faced technical problems both as moderator and the participants. As the moderator, during lockdowns, I conducted most of the interviews from home with my unlimited wireless connection up to $100 \mathrm{Mbps}$ with which I had many problems from disconnections to asynchronous voice and video, from unstable connections to freezing screens and so on. Speculating on my internet speed, I, then, upgraded it to $200 \mathrm{Mbps}$ and tried to eliminate these problems, which were mostly solved. In partial normalization processes, yet, I preferred conducting the interviews from the Institute with wired network facilities of the university where I had no connection problems in the interviews. Beyond, since I encountered some troubles with the camera and microphone features of my personal computer, I had to change it with a new model to enhance and ensure the quality of the interviews and data. A bright and silent room which I predicted that nobody would interrupt during the interview felt comfortable for me, on the other hand.

As for the participants, we witnessed the same technical problems, the ones who attended the interviews through their personal connections experienced more disturbances than the ones with institutional connections. What is more, the place where they attended the interviews were not always silent, belong only to them, and/ or even stable. In these situations, I implicitly requested the participants to share their disturbances with me and the group participants so that the group could adapt itself and embrace the situation without putting each other out of sorts. In so doing, when one faced any technical problem, the whole group worked for a solution without having a motivation and/or concentration loss, which, in contrast, created a friendly and cheerful atmosphere within the group.

\section{After the Online Fieldwork: Final Inspections}

In qualitative research, some incentives are offered for the participants before or after the interview or focus group discussions. In our study, we did not offer any incentives. Following the last question of the interviews and focus groups discussions, almost all participants expressed that they were pleased to participate in the research, learnt a lot, met new people and would like to continue the communication after the fieldwork. Moreover, some participants stated that they would like to read the results of the research, and some of the NGO members suggested to use the results of the study for advocacy in their work. Especially in focus groups, the existence of different perspectives from the same/similar and/or different fields revealed the professional deformation that participants had gone through, and seeing this impressed almost all of them. Moreover, in both homogenous and heterogeneous focus group discussions, bringing non-acquainted people thinking and working on similar issues created an atmosphere of solidarity and a will to pursue this friendship. However, what is more significant and necessary to be underlined, most of the participants indicated that they would not have been able to attend the interviews if it had not been online with reasons like busyness, lack of time, low psychological and physical energy, children's care, pregnancy, elderliness, work, and similar. It may also be vital to indicate that we did not receive any refusals to attend the interviews showing online interviewing as reason, all of our refusals were due to busyness.

Immediately after the interviews ended, I once again sent an e-mail to the participants to thank for their participation and contribution. While Zoom application was converting the interview, I wrote my observations about the interview and/or downloaded Google Form sheets of the focus group. When the record was converted I did the final checks, and backed up all files both in memory cards and Google Drive. In in-depth interviews, I shared the records with the participant if $s$ /he requested while, in focus groups, I did not share any records so as not to violate the rights of any participant. 
I ended the fieldwork up in late July, 2021, with 22 in-depth interviews and 6 focus group interviews composed of 2 heterogeneous and 4 homogenous focus groups. In-depth interviews lasted for 1 to 3,5 hours while focus group interviews took 2-2,5 hours at most.

\section{WHAT WE HAVE LEARNT FROM ...}

As literature supports, online fieldwork brings ads and cons together; however, in this study, instead of discussing the ads and cons in a dichotomous way, we prefer approaching them from the aspect of specificities of the situation. An advantage can turn out to be a disadvantage in another situation, and/or a situation that online interviews put forth can simultaneously be negative and positive, we witnessed this for several times in our field. Therefore, we would like to discuss the topic not over ads and cons but over our specific experiences.

Accustomed to traditional qualitative research methods, we were worried about the opinion of an online fieldwork. These worries include the risk of being unable to reach at targeted sampling, having poor quality data due to technical problems, the possibility of failure in creating a qualitative atmosphere in an online platform, security problems and related refusals as well as ethical weaknesses. At the end, though, we realized that the data we generated during the fieldwork could not have been produced in traditional ways. Definitely first to mention, in both in-depth interviews and focus groups, online interviewing provided us with a tremendous diversity and multiplicity in sampling and recruitment. We were in Ankara and the participants were all around the world. Especially in focus groups, it was very effective to have participants from different cities and countries, which supplied the group with different geographical observations and examples in addition to common thoughts and feelings on the same subjects and questions. In traditional interviewing, enabling this would cost incomparable chance, budget, time and energy. Besides, if it were not online, I would be limited with Ankara due to lack of budget and I would not have the chance of conducting such an extended sample comprised of 56 participants.

The other point is the issue of time. I have conducted these interviews in 5 months due to my methodological requisitions. As researchers, we evaluate this as a fast and fruitful field. With travels, busyness of the participants, tiredness and organization processes this would have been longer in traditional fieldwork. As for the participants, on the other hand, this situation has an ambivalent aspect. Participants did not need to make travels before or after the interviews/focus groups even within their cities. They could attend the interview from where they were to be: homes, university rooms, working places, cars, museums and even from exhibitions. This was both an opportunity and a weakness. In one hand, our research could host mostly disadvantaged groups that probably could not be included in traditional methods if they were not the direct targets such as pregnant women, mothers with small children, working women, the unemployed, people in rural areas, old and/or sick people and so on. On the other, attending from where they were reduced the possibility of focusing only on the group and the discussions which would much be easy in a room and a period completely dedicated for this purpose. I observed that during the interviews some participants attending from work were interrupted by telephone calls, knocking doors and visitors, and participants attending from home simultaneously replied to the needs of the household, while participants attending from outside places were disturbed with other atmospheres and necessities. Although they were actively participating they were also in another place physically and this seemed like a bifurcation of consciousness in space. For this, I indicated in my e-mails the ideal properties of the place they were to attend the interview so that they could prepare themselves and their environment if they had the chance. Relatedly, I realized that participants who preferred attending with off-cameras were less attached to the group and discussions and felt the need of introducing themselves and/or greet the group once again each time they took the floor. I carefully watched whether this feeling of alienation would reciprocally transmit to other participants or not, yet it did not.

Another ambivalent return of the online interviewing is that it is open to not only last-minute cancels but also last-minute attendances. Especially in focus group interviews, this situation created both disturbances and happy moments. Since we had set a minimum limit of 6 participants for our focus group interviews, last-minute withdrawals brought the risk of cancelling the interview which had been organized days before with difficulty to find the common day and hour for all group members. However, the same situation brought the solution with it as well by the opportunity of including another participant with the same speed. These are highly stressful 
moments that test the researchers' thinking, deciding and acting abilities under pressure. Once, in the first focus group discussion, I had to comply with 4 participants and it was inevitable due to the last-minute withdrawals of particularly selected participants of specific public institutions due to convergent meetings.

Besides, as the interviewer/moderator, I felt the urge of looking at myself on the camera during the interviews, this was disturbing in the beginning of an interview. I, at the first sight, had evaluated this situation as negative and wished that I could have minimized my picture ratio. However, then, during the transcriptions, I realized that I had been concentrated on the interviews immediately after the introduction, and as it was revealed by my gestures in the records, I had totally forgotten myself through the interviews. That was a big surprise for me and I have learnt a lot from my mimics by means of online interviewing and evidently realized the importance of gestures and facial expressions in qualitative research which previously I knew only by heart. On the other hand, this can be evaluated as an opportunity in catching the visual signs of agreement/disagreement and/or non-verbal facial clues of the participants through the records that can be missed in face-to-face interviewing.

\section{IN LIEU OF CONCLUSION}

We know that, stimulated by the pandemic, online interviewing will continue to draw the attentions of the qualitative researchers. In this paper, we have shared our own experiences driven by a 5-month-fieldwork. We have found out that the studied topic is one of the key determinants of the course of an e-field. Similarly, the advantages and disadvantages of online interviewing can situationally turn into a slippery ground to stand on. We have even learnt a situation can bear both ads and cons that force us to make a selection.

What is incontestable, the quality of network facilities, equipment, and place of attendance to an interview adds to the quality of the interview and data generated out of it. Yet, when psychological connections are ensured between the participant and the interviewer and/or among the participants, physical or virtual connection problems can fade away. With technical precautions and strategies along with personal and ethical elegancy before, during and after conducting the interviews, this process can be turned into a very effective, enjoyable, fruitful and friendly experience.

We cannot say that online interviewing costs less. With the technical requirements of online interviewing including the equipment, network packages and application fees, we think it is equally significant to think over. On the other hand, the opportunity of having participants simultaneously from all over the world is beyond price. In this experience, with a diversity and multiplicity of participants, we conducted a fast online fieldwork, which happened to be very rich and productive.

Acknowledgements: We would like to thank Dr. Hilal Arslan, Hakan Türkoğlu and Dr. Hasan K. Akcan for their technical support during our fieldwork.

\section{REFERENCES}

American Association for Public Opinion Research (AAPOR). (2020). Covid-19 Workshop Series: Covid-19 Changes to Research Practices. https://www.aapor.org/Conference-Events/COVID-19-Workshop-Series.aspx

Adalı, T., Koyuncu, Y. \& Türkyılmaz, A. S. (2021). Surveys in Covid-19 and Post Covid-19 Days. UNFPA Turkey. Retrievable from https://turkey.unfpa.org/en/publications/surveys-covid-19-and-post-covid-19-days

Beddows, E. (2008). The Methodological Issues Associated with Internet-Based Research. International Journal of Emerging Technologies and Society, 6(2): 124-139.

Bloor, M., Frankland, J., Thomas, M. \& Robson, K. (2001). Focus Groups in Social Research. Sage Publications.

Blumer, H. (1969). Symbolic Interactionism: Perspective and Method. New Jersey: Prentice-Hall.

Creswell, J. W. \& Creswell, J. D. (eds.). (2018). Research Design: Qualitative, Quantitative, and Mixed Methods Approaches (5 $5^{\text {th }}$ Edition). Sage Publications, Inc.

Denzin, N. K. \& Lincoln, Y.S. (1998). Strategies of Qualitative Inquiry. London: Sage Pub.

Dogan, O. (2020). Are online researches scientific? Anatolian Journal of Psychiatry, 21 (6): 656-661. 
Fairclough, N. (1992). Discourse and Social Change. Cambridge: Polity.

Garfinkel, H. (1967). Studies in Ethnomethodology. New Jersey: Prentice-Hall.

Glesne, C. \& Peshkin, A. (1992). Becoming Qualitative Researchers: An Introduction. New York: Longman.

Haraway, D. (1991). Situated knowledges: The science question in feminism and the privilege of partial perspective. In Simians, cyborgs, and women: The reinvention of nature. New York: Routledge.

Hewson, C. M., Laurent, D. \& Vogel, C. M. (1996). Proper methodologies for psychological and sociological studies conducted via the Internet. Behaviour Research Method, Instruments and Computers, 28: 186-191.

Karakulakoğlu, S. E. (2014). Internet Araştırmalarında Yöntem Sorunu. Erciyes İletişim Dergisi "akademia", 3(4):122-134.

Lobe, B., Morgan, D. \& Hoffman, K. A. (2020). Qualitative Data Collection in an Era of Social Distancing. International Journal of Qualitative Methods, Volume 19: 1-8.

Lupton, D. (ed.). (2021). Doing fieldwork in a pandemic (crowd-sourced document), revised version. Available at: DOING FIELDWORK IN A PANDEMIC

Mason, J. (2002). Qualitative Researching. Sage Publications, Inc.

Mehda, R. \& Sivadas, E. (1995). Comparing response rates and response content in mail versus electronic mail surveys. Journal of Market Research Society, 37: 429-439.

Morgan, D. L. \& Krueger, R.A. (1998). The Focus Group Kit. Sage Publications, Inc.

Saldaña, J. (2010). Writing Ethnodrama: A sampler from educational research. In M. Savin-Baden and C. H. Major (eds), New Approaches to Qualitative Research: Wisdom and Uncertainty (pp. 61-70). London and New York: Routledge.

Savin-Baden, M., Gourlay, L. \& Tombs, C. (2010). Researching in immersive spaces. In M. Savin-Baden and C. H. Major (eds), New Approaches to Qualitative Research: Wisdom and Uncertainty (pp. 162-172). London and New York: Routledge.

Savin-Baden, M. \& Major, C. H. (eds.). (2010). New Approaches to Qualitative Research: Wisdom and Uncertainty (pp. 61-70). London and New York: Routledge.

Schutz, A. (1976). The Phenomenology of the Social World. London: Heinemann.

Stanley, L. \& Wise, S. (1993). Breaking Out Again: Feminist Ontology and Epistemology. London: Routledge.

Sociology Association. (2021). Salgında Sosyolojik Araştırma: Sınırlılıklar ve Yeni Tahayyüller [Sociological Research in the Pandemic: Limitations and New Imaginations]. Online Workshop. https://sosyolojidernegi. org.tr/salginda-sosyolojik-arastirma-sinirliliklar-ve-yeni-tahayyuller-cevrimici-atolye/

Tates, K., Zwaanswijk, M., Otten, R. et al. (2009). Online focus groups as a tool to collect data in hard-toinclude populations: examples from paediatric oncology. BMC Med Res Methodol 9, 15. https://doi. org/10.1186/1471-2288-9-15

Wetherell, M., Taylor, S. \& Yates, S. J. (2001). Discourse Theory and Practice: A Reader. London: Sage Pub.

World Association for Public Opinion Research (WAPOR). (2020). WAPOR webinars: Changes in Survey Research in Times of Covid-19 (May 2020). https://wapor.org/resources/wapor-webinars/webinar-may-2020/

\section{Beyan ve Açıklamalar (Disclosure Statements)}

1. Bu çalışmanın yazarları, araştırma ve yayın etiği ilkelerine uyduklarını kabul etmektedirler (The authors of this article confirm that their work complies with the principles of research and publication ethics).

2. Yazarlar tarafından herhangi bir çıkar çatışması beyan edilmemiştir (No potential conflict of interest was reported by the authors).

3. Bu çalışma, intihal tarama programı kullanılarak intihal taramasından geçirilmiştir (This article was screened for potential plagiarism using a plagiarism screening program). 